ALINA PAPATS,

\title{
INSTITUTIONS OF SECONDARY EDUCATION IN KATERINOSLAV PROVINCE IN THE EARLY XXth CENTURY AND LEARNING FEATURES (Cases of Katerinoslav male gymnasium and Mariupol Mariinsky female gymnasium)
}

\begin{abstract}
Relevance of the article is due to the need to present valuable experience of private and public education gained by educational institutions that were on the territory of modern Ukraine in the early XXth century.The number of students of Katerinoslav male gymnasium and Mariupol Mariinsky female gymnasium in the early XXth century is analyzed in the article. The features of their education in these secondary education institutions are revealed: the subjects and programs, tuition fees, help to poor but talented students (scholarships, etc.). It is shown that in the early XXth century the number of students in secondary education institutions increased, which led to the opening of new educational institutions in Katerinoslav Province. The quantitative composition of students in different years in male and female educational institutions of that period and their social strata are characterized. It is shown that not only state secondary education institutions were opened, but also private ones. This period is emphasized the establishment of various public organizations that took care of education development. Philanthropy in the sphere of education among the local elite and business community reached a significant scale. Thus, it is proved that the reform of the secondary school, though it hasn't not received legislative support in the Russian Empire, but it was put into practice, that led to the growth of the number of private educational institutions, as well as public and charitable initiatives related to the education of insolvent population. Coverage of the work of individual educational institutions during that period gives an opportunity to get an idea of the Russian government;s domestic policy concerning education, to draw conclusions about the level of literacy and education and the social structure of education.
\end{abstract}

Key word: secondary education institutions; Katerinoslav Province; students; male gymnasium; female education.

\section{Introduction}

A strong state and competitive economy can provide a united community of creative people, responsible and active citizens. Such citizens should be trained by educational institutions. The content of professional (vocational), professional and higher education should be constantly updated to meet the needs of the labor market. For this purpose, it is necessary to study the past historical experience. In recent decades in Ukraine there is a complex and controversial process of secondary education reforming, its adaptation to high qualification standards and requirements of European countries. Providing the necessary quality, the most effective and costeffective scenario for the development of the system of training of teaching specialists is impossible without a wide logistical support of both teachers and the school itself. Research and analysis of the development of the secondary education system is an important condition for the actualization of experience and ideas that have been accumulated during the existence of this system, which will contribute to the revival of the national teacher training school. In general, the study of the development of

ISSN 1728-9343 (Print)

ISSN 2411-3093 (Online) secondary education in Katerinoslav province in the early XXth century. gives us an opportunity to see that in the history of our domestic education there are many valuable elements that have not lost their relevance and could be used to update the modern school in Ukraine today. Among them there are directions of theoretical and practical experience of the period under study, which can be relevant and used in solving the tasks of the present time.

The purpose of the study is to review the number of students and the peculiarities of their studies in Katerinoslav Province in the early XXth century. Tasks of the article are: to characterize the quantitative composition of male and female students of secondary education institutions of the marked period; to reveal the peculiarities of studies: curriculum, subjects, material and living conditions of students.

This topic was studied by historians and local historians. S.Siropolko in his work "History of Education in Ukraine" (2001) gave an overview of the development of male and female secondary education in that period. F. Lokot in his work "Historical note on the centennial existence of the Katerinoslav Classical male gymnasium" 
(1908) revealed the development of the Katerinoslav male gymnasium from its opening to the centenary of its existence. I.Alyoshintsev in his work "The History of Gymnasium Education in Russia (XVIII and XIX centuries)" (1912) reviewed the development of secondary education from the viewpoint of the imperial government and modernization processes that took place there. $\mathrm{P}$. Sokolov revealed the historical development of Katerinoslav female Gymnasium for the first century of its existence in his work "Historical note about the 1st City female Gymnasium to the 25th anniversary of its existence" (1909). V. Shandra in her work "Factors of growth of the role of women in public life of Ukraine (1880s - early XX century)" (2012) showed the role and impact of female education on the development of society of those times.

\section{Research methods}

Methodological principles of this theme are based on the following scientific principles: historicism, objectivity, consistency, comparison and scientific pluralism. The principle of historicism determines the study of the phenomena and processes under study in accordance with the specific historical situation, gives an opportunity to recreate in the dynamics the real picture of the quantitative composition of secondary school students in Katerinoslav province and the peculiarities of their studies in the early XXth century. The principle of objectivity helps to assess the reliability of the used sources critically, to minimize bias in the analysis of events, which contributes to an objective assessment of the development of secondary education in Katerinoslav region in the given period. The system approach provides the analysis of activity of separate components of the region's education system and educational activity in the specific conditions of the marked period. The comparative principle makes it possible to determine the characteristics of the secondary education in different educational institutions and to identify the differences between male and female education. The principle of scientific pluralism provides for the consideration of historical phenomena, taking into account all the theories and methods of research, which makes it possible to study the quantitative composition of students and the characteristics of their studies in the given period in Katerinoslav province.

\section{Results and discussion}

In Russian Empire the industrial revolution finished later than in all big countries in the late XIXth century. It took place simultaneously with industrialization, which led to a high concentration of production and rapid economic development. But the working conditions were very difficult, which led to a working strikes throughout the empire in the early XXth century. This time was also the time of the great economic crisis (1900-1903), of the RussianJapanese War (1904-1905), which Russia lost. All these events could not but affect the development of certain provinces, and also Katerinoslav. But secondary education continued to develop during this difficult time for Russian Empire. Especially during the intensive development of the economy between 1905 and 1913, which contributed to the formation of a fairly strong rich sector of the population, such as bourgeois and merchants. It is thanks to their funds, which they allocated for the development of education, the state of financial support and educational and material base of most gymnasium institutions has significantly improved. This contributed to the creation of new gymnasium institutions, the reorganization of previously established ones, and growth in the number of students (Siropolko, 2001).

As the number of secondary education institutions grew, so did the number of students who received education there. In the early 20th century the Katerinoslav male gymnasium consisted of the main two-storey building, which included: an outbuilding with the headteacher's apartment, an archive, an office, a maid's room, and 5 stone buildings in the yard (Lokot, 1908).

In the early XXth century, the number of students of Katerinoslav male gymnasium was as follows: in 1900 284 students studied at the gymnasium, in $1901-338$, in 1902 - 356, in 1903 - 390, and in 1904. there were 430 students. Moreover, the gymnasium did not always have the opportunity to accommodate all students. For example, in summer, 1904, the entry exams for the first grade of the gymnasium passed 83 students, while the gymnasium could accept only 40 . Only with the opening of the parallel department it became possible to enroll them to the educational institution.

The vast majority of students were children of noblemen and officials $(52.3 \%)$, while the rest were children of not-noble families (clergy - 6.74\%, urban residents $32.3 \%$, peasants $-7.4 \%$ ) (Lokot, 1908).

Particular attention is paid to the age of graduates. Thus, for example, according to the Ministry of Public Education in 1906 gymnasiums leavers: 17 years-oldstudents - 4.9\%, $18-22.9 \%, 19-28.8 \%, 20-22 \%, 21$ and more $-21.1 \%$ (Humble report, 1908).

The cost of education was established in the late XIXth century, in 1899, by the Ministry of National Education and it was 60 rubles. Poor students who could not pay for their studies received personal scholarships and they paid for their studies. Since 1900 the number of students began to grow.

In general, gymnasiums taught subjects that could be of practical use in the future after graduation. In the lessons of the Russian language it was developed the ability express student's views clearly and competently, which would later help in business communication between people; in the lessons of foreign language they were taught to read and write quickly; in mathematics - to work with numbers and spatial concepts. Graphics lessons were supposed to develop the ability to provide an accurate drawing of the subject, and others. Teaching history was considered to be dangerous because it could lead to "wrong or even harmful" judgments (Piskunov (ed.), 1976).

After graduating from high school, graduates continued their education quite easily in different European countries (Pleteneva, Barinova, 2016). Therefore, the dominant position of the old languages was gradually lost, and students began to study Russian and European languages, history, geography more deeply. The number of teaching hours from these subjects was increased. In the early XXth century, a part of science subjects increased to $25 \%$ of the course. Since 1905-1906 academic year teaching of philosophical propaedeutics and law was introduced in gymnasiums (Alyoshintsev, 1912).

Students who wished to continue their studies or who had benefits when they joined the civil service must have had a grammar school certificate. For the final examinations, a commission headed by the head teacher of the gymnasium was established. Students who had a "significant degree 
of moral immaturity" during the eighth grade, as well as those who had one unsatisfactory grade in a subject during the year were not allowed to take these examinations. Students took the following exams: Law of God, Russian, Latin, Greek and German, French, mathematics, history. For languages and mathematics, the exams were written and oral. For written subjects it was necessary: to write a work, translate from Russian into the ancient languages, do sums in algebra and geometry. Writing the work lasted 5 hours, translation - 4 hours, mathematics - 5 . Written exams took place within a week. Oral exams also lasted one week (Collection of orders, 1867).

Those who graduated from the gymnasium well were awarded gold and silver medals. Another condition of getting a medal was excellent behavior (Lokot, 1908).

Oleksandrovskaya female gymnasium in Mariupol took a significant place in the education system of that time, which was opened in 1876 . In the early years, the number of students remained small, but in the early twentieth century, the number of students who were getting education increased: in 1902 there were 401 students, and in 1905. - 493. The institution had thirteen classes: eight basic, four parallel classes and the primary one (Mikhailova, 2012).

Taking into account the growth in the number of students, the management of the gymnasium and the city council paid considerable attention to strengthening and improving the material and technical base and adding to the library collections. The gymnasium had well-equipped classrooms (physical, natural-historical, drawing) and museums (historical-geographical, historical-church-archeological), which had a positive impact on comprehensive awareness of students and quality of lessons.

At the end of the XIX century, another male progymnasium was opened in Lugansk - the center of Slovyanoserbskiy district. The gymnasium was first opened as a 4-grade school, in 1901 it was transformed into a 6-grade school, and from the beginning of the 1903-1904 school year - into a full gymnasium. In 1907 it was attended by 336 students (Kurilo, Podov, 1901).

Mariupol female Mariinsky gymnasium in Mariupol in the early XXth century occupied one of the leading positions in female education in the province. Studies were paid. With the beginning of the new century fees were increased, not everyone was able to pay for it. As in Katerinoslav male gymnasium, scholarships for poor but talented children were founded (Shandra, 2012). There were 30 scholarships in the gymnasium, which allowed children from poor families to study for free. Also, some of the students received help from the "Society for Assistance to poor female Gymnasium Students. In 1902, the Society paid 45 students for the tuition of 1,190 rubles. It had funds from membership fees and little interest from fixed capital, but there were not enough of them to provide assistance to the poor (Moroz, 1994).

Teaching was at a high level. Except basic course, girls studied handicraft, dancing, hygiene. Much attention was paid to general education of girls. It was obligatory to plant trees every spring. Gymnasts participated in sports competitions, performances, went on excursions. Having acquainted with the customs and regulations of the gymnasium, we can safely conclude that modern girls were luckier than gymnasts, because the girls were looked after by so-called class supervisors even in their spare time. All the mistakes of girls were recorded in the so-called Conduit list (penalty book).
Girls necessarily went in the same uniform and the same shoes (Demidko, 2018).

On January 1, 1900, Katerinoslav Mariinsky female Gymnasium had 12 classes: senior, junior preparatory, 7 basic, 2 parallel and eighth pedagogical. If in the first year (1876) the gymnasium welcomed 129 students, in the early XXth century, their number increased to 647 .

The main source of maintenance for the gymnasium was the tuition fees. The gymnasium was also provided with annual help of 300 rubles from the local budget (Report on the condition, 1900).

In the early $X X$ th century, the premises were overhauled and the new building was completed. This immediately made it possible to increase the number of female students. In 1904, the gymnasium had thirteen large classrooms. The new premises of the gymnasium had seven main classes, preparatory, eighth additional and four parallel. Also, since the late XIXth century there was a free class for very poor girls (Report of of Zemstvo ...,1903). From the very beginning of the gymnasium, the Board of Trustees decided to exempt from tuition fees $10 \%$ of all students.

However, in 1907, at the suggestion of the City Duma, it was taken a decision to exempt from payment only gymnasium teachers' children. As for others, a significant part of the students was exempted from school fees, either at all or in part, through the donation from funds, from charity lotteries, from the sale of handicrafts, and so on. Several students were exempted from payment and received help as scholarship holders. This number sometimes reached a one third or more of those who studied (Sokolov, 1909).

One of the main problems of the gymnasium was the lack of proper premises, because the number of students increased every year and they had to find new premises every year. Therefore, in 1907, tuition fees were increased: for studies in the preparatory class - up to 35 rubles, and in the upper classes - up to 50 rubles, in the eighth grade - up to 80 rubles per year. The actual cost of study significantly exceeded the established fee: in 1907 the study of one student was on average 81 rubles. 82 cop. (Sokolov, 1909).

Children of different faiths and social backgrounds studied at the gymnasium. On January 1, 1908 Orthodox students were $73.38 \%$ of 511 students, then were students of Jewish faith - 19.37\%. Interesting changes took place in the social composition of the gymnasium students. For example, the number of female students of peasant status increased from $6.25 \%$ in 1902 to $13.11 \%$ in 1908, that is, more than twice. In contrast, the number of gymnasium students of noble and official origin decreased from $38.07 \%$ in 1901 to $23.28 \%$ in 1908 . As for other social groups, $3.52 \%$ of the students were clergy children, $10.17 \%$ were children of merchants of the $1 \mathrm{st}$ Guild and of honorary citizens, $46.38 \%$ were children of bourgeois, merchants of the 2nd guild and craftsmen, $0.78 \%$ were Cossacks, and $2.54 \%$ of other states. That is, the main contingent of the gymnasium consisted of children of bourgeoisie and craftsmen and children of lowincome urban population (Sokolov, 1909).

A small hostel was founded, which was opened on November 12, 1912. The nobility spent an average of 6,000 rubles on the maintenance of Katerinoslav boarding house. In 1912, 6 girls were admitted to the boarding house, 5 of which were exempt from paying tuition. In 
1913 their number increased to 19 with 14 exempt from paying tuition fees.

The overcrowding of the Katerinoslav female Gymnasium led to the opening of the 2nd city female gymnasium in 1908. The following year, in 1909, it was decided to open a third city female gymnasium.

In addition to these state institutions of female secondary education in the early $X X$ th century in Katerinoslav eight private female gymnasiums were opened: the female gymnasium O.G. Petrova (1904), the female gymnasium N.E. Bittner (1905), the female gymnasium of S.I. Stepanova, (1905), female Gymnasium of N.M. Tiblin (1906), female Gymnasium of P.L. Ioffe (1907), female Gymnasium of R.F.Vashchuk (1907), the Jewish female gymnasium of S.M. Yudkovich (1909), the female gymnasium of N.G. Butovich and a private secondary school for girls (under the program of the male gymnasium), founded by I.F. Vertogradov (Ekaterinoslav address-calendar, 1917).

\section{Conclusions}

Thus, we can conclude that in Katerinoslav Province in the early XXth century, the number of institutions for male and female education was growing, because the need for them increased because of overcrowding of existing educational institutions. They were opened not only in the provinces, but also in county towns and villages. In the early XXth century, not only public, but also private secondary education institutions, especially female, began to open. In their educational activities, private individuals were guided by the following goals: preparing students for work in private enterprises and the desire to provide quality education to the general public, the study of talented and gifted children, which attracted the attention of the masses to education. Poor students had the opportunity to receive education and pay for it through the introduction of scholarships. The material condition of educational institutions was improved by state subsidies, private donations, and increased tuition fees. In general, with the development of capitalism in Russian Empire and the occasional need for experienced workers, the number of students in secondary schools increased significantly in the early XXth century. The subjects were also taught in accordance with the time and needs of society. Graduates of these educational institutions were prepared for life and work immediately. The curriculum was developed in such a way that students graduated with deep of knowledge and ability to communicate. This was also the purpose of the final exams.

\section{REFERENCES}

Alyoshintsev, I.(1912). History of gymnasium education in Russia (XVIII and XIX centuries). St.Petersburg, 346 p. (In Russian).

Collection of orders for the Ministry of Public Education (1867). Circular proposal for the introduction of new distributions of subjects and lessons by class and a special distribution of mathematics teaching from May 14, 1852. St.Petersburg. Vol-3. 1850-1864. (In Russian).

Demidko, Olga. (2018, February 28). History of the oldest school in Mariupol. MRPL.CITY. Retrieved from https://mrpl.city/blogs/view/istoriya-najstarishoi-shkoli-mariupolya (Accessed 29 November 2020).

Ekaterinoslav's address-calendar. (1917) Katerinoslav, $430 \mathrm{p}$.

Humble report of the Minister of National Education for 1906. (1908). St. Petersburg. 251 p. (In Russian).

Kurilo, V.S., Podov, V.I.(1999). Education in Donbass (XIX early $X X$ centuries). Lugansk: LSPU, 114 p. (In Ukrainian).

Lokot, F.(1908). Historical note on the centennial existence of the Katerinoslav classical male gymnasium. Katerinoslav, $386 \mathrm{p}$. (In Ukrainian).

Mikhailova, D.V.(2012). An outstanding role of F. Khartakhay in the opening of the first Mariupol gimnasium. National Pedagogical Journal of the National ped.University by M.P.Dragomanov: Serie 16. Teacher's Creativity: Problems of Theory and Practice.17 (27). P. I: 76-81 (In Ukrainian).

Moroz, B. (1994). The first weak light of female education lit in our city Alexandra Akimovna Ryndovskaya. Dnieper Vecherny. August, 27 (In Ukrainian).

Piskunov, A.I. (ed.) (1976). Essays on history of school and pedagogical thought of the peoples of the USSR. The second half of the XIX century. Moscow: Pedagogy, 600 p. (In Russian).

Pleteneva, I.F., Barinova, L.V. (2016). Establishment and Development of Gymnasium Education in Russia in the XVIII-XIX Centuries. Psikhologiya i pedagogika: metodika i problemy prakticheskogo primeneniya. 48. Retrieved from https://cyberleninka.ru/article/n/stanovlenie-i-razvitie-gimnazicheskogo-obrazovaniya-v-rossii-v-hviii-hix-vv (Accessed 27 November 2020).

Report of Zemstvo of Katerinoslav Province, 1901. (1903). Katerinoslav. PART II. $163 \mathrm{p}$

Report on the condition of the Mariupol female gymnasium for 1899 civil year. Mariupol. (1900). 46 p.

Shandra, Valentina. (2012). Factors of increasing role of women in public life of Ukraine (1880th century - 20th century). Przeglad zachodniopomorski. XXVIII (LVI), 2: 77-87 (In Ukrainian).

Siropolko, S. (2001). Istoriya osvity v Ukrayini. Lviv: Afisha. 664 p. (In Ukrainian).

Sokolov, P.A. (1909). Historical note about the 1st City female Gymnasium to the 25th anniversary of its existence. Ekaterinoslav, $180 \mathrm{p}$.

Аліна Папац,

Маріупольський державний університет (Украӥна)

e-mail: alinasch48@ukr.net, ORCID 0000-0002-9001-219X

\section{ЗАКЛАДИ СЕРЕДНЬОЇ ОСВІТИ КАТЕРИНОСЛАВСЬКОї ГУБЕРНІЇ НА ПОЧАТКУ ХХ СТ. ТА ОСОБЛИВОСТІ НАВЧАННЯ (КеЙСИ КатерИНОсЛवВСьКої чолові- чої гімназії та Маріупольської Маріїнської жіночої гімназії)}

Актуальність статті зумовлена необхідністю презентації цінного досвіду приватної та державної освіти, набутого освітніми закладами, що функціонували на території сучасної України на початку XX ст. Проаналізовано кількісний склад учнів Катеринославської чоловічої гімназії та Маріупольської Маріїнської жіночої гімназії у цей період. Розкрито особливості навчання в цих закладах середньої освіти, а саме: навчальні предмети та програми, плата за навчання, допомога у вигляді стипендій бідним, але таланови- 
тим учням. На початку XX ст. кількість учнів в закладах середньої освіти зросла, що призвело до відкриття нових закладів освіти у Катеринославській губернії. Охарактеризовано кількісний склад учнів в різні роки в чоловічих та жіночих закладах освіти у зазначений період, їх соціальний склад. Показано, що відкривалися не тільки державні заклади середньої освіти а й приватні. Характерним для цього періоду було створення різноманітних громадських організацій, які опікувалися розвитком освіти. Значних масштабів досягла благодійність у сфері освіти представників місцевої еліти та ділових кіл. Таким чином доведено, що реформа середньої школи хоч і не отримала в Російській імперії законодавчого підкріплення, проте втілювалась на практиці, що багато в чому виражалося в збільшенні кількості приватних навчальних закладів, а також у громадських та благодійних ініціативах, пов'язаних з освітою неплатоспроможних верств населення. Висвітлення роботи окремих навчальних закладів освіти в цей період дає можливість отримати уявлення про внутрішню політику російського уряду в частині освіти, зробити висновки про тодішній рівень грамотності та освіти та про соціальну структуру освіти.

Ключові слова: заклади середньої освіти; Катеринославська губернія; учні; чоловіча гімназія; жіноча освіma.

(C) Alina Papats

Надійшла до редакції: 11.08.2020

Прийнята до друку: 01.11.2020 